\title{
Sanal Üretim ve Sanal Tüketim Bağlamında Bilgisayar Oyunları ve Boş Zaman Kavramı: Farmvılle Örneği
}

\author{
Onur Taydaş (Dr. Öğr. Üyesi) \\ Sivas Cumhuriyet Üniversitesi İletişim Fakültesi \\ onurtaydas@cumhuriyet.edu.tr \\ Orcid: 0000-0002-5068-8988 \\ Enderhan Karakoç (Doç. Dr.) \\ Selçuk Üniversitesi İletişim Fakültesi \\ enderhan@selcuk.edu.tr \\ Orcid: 0000-0001-8969-6144
}

Başvuru Tarihi: 10.05.2019

Yayına Kabul Tarihi: 11.06.2019

Yayınlanma Tarihi: 22.07.2019

DOI: 10.17680/erciyesiletisim.562713

Taydaş, O. ve Karakoç, E. (2019). Sanal Üretim ve Sanal Tüketim Bağlamında Bilgisayar Oyunları ve Boș Zaman Kavramı: Farmvılle Örneği. Erciyes İletişim Dergisi, 6 (2), 1191-1208.

DOI: $10.17680 /$ erciyesiletisim. 562713

Öz

Bireylerin zamanlarının büyük bir kısmını kitle iletişim araçlarıyla geçirdikleri bilindiği için, kitle iletişim araçlarına ayırdıkları zamanın onların hayatlarını ne yönde etkilediğini konu edinen araştırmalar literatürde fazlasıyla bulunmaktadır. Son zamanlarda ise bu araştırmalara ek olarak bireylerin sosyal medyaya ayırdıkları zamanı ve bu zamanın bireylerin yaşantısına etkisi de yeni yeni incelenmeye başlanmıştır. Bu konuyla ilgili literatüre bakıldığında sıklıkla bireylerin sosyal medyada geçirdikleri zamanın ne derece etkili olduğu, ne kadar süreyi sosyal ağlara ayırdıkları ya da sosyal ağları neden bu kadar sık kullandıkları ayrı ayrı sorgulanmaktadır. Bilindiği üzere sosyal ağlarda insanların diğer insanları takip etmelerinin temel amaçlarından birisi bir şeylerden haberdar olmaktır. Fakat aynı zamanda aynı bireyler sosyal ağları oyunlar oynamak içinde kullanmaktadır. Üyelerine farklı sebepler sunmanın yolunu arayan sosyal ağlar eğlence özelinde sundukları bu oyunlar ile isteklerine ulașmıș bulunmaktadır. Bireylerin başlıca sosyal ağlarda neden oyun oynamayı tercih ettiklerini anlamaya yönelik hazırlanan bu çalışmada bireylerin, sanal dünyada üretim yapmayı neden tercih ettikleri, boş zamanlarını neden bu oyunla geçirdikleri incelenmiştir. Sanal üretim, sanal dağıtım ve sanal tüketim üzerine kurulu mantığıyla dünyada en fazla oynanan oyunlardan birisi olan FarmVille bu kapsamda çalışma için seçilmiş, bu oyunu oynayanlar çalışmanın eksenine dahil edilmiştir. Ayrıca çalışmada ölçme aracı olarak ankete başvurulmuştur. Araştırmaya katılan bireylerin, FarmVille oyununu oynadıkları zamanlar incelendiğinde katılımcılardan erkek ve kadınların yaklaşık \%80'ninin günlük iki saatlerini bu oyuna ayırdıkları belirlenmiștir. Dolayısıyla modern insanın en büyük sorunu olarak dile getirilen zamanın belli bir kısmının oyunlarda geçirilmesi, bireylerin rahatlamaya ve sorumluklardan, sorunlardan kaçmaya ne kadar ihtiyaç duyduklarını göstermektedir. Araştırmada elde edilen sonuçlar kısaca değerlendirildiğinde; katılımcıların çoğunlukla sosyalleşme, boş zaman değerlendirme, rahatlama, sorunlardan ve sorumluklardan kaçma gibi sebeplerle oyunu tercih ettikleri görülmüştür.

Anahtar Kelimeler: Boş Zaman, Serbest Zaman, Oyun, FarmVille, Sanal Üretim, Sanal Tüketim. 


\title{
Computer Games and Leisure Time Concept In the Context of Virtual Production and Virtual Consumption: Farmville Example
}

\author{
Onur Taydaş (Asst. Prof. Dr.) \\ Sivas Cumhuriyet University Faculty of Communication \\ onurtaydas@cumhuriyet.edu.tr \\ Orcid: 0000-0002-5068-8988 \\ Enderhan Karakoç (Assoc. Prof. Dr.) \\ Selçuk University Faculty of Communication \\ enderhan@selcuk.edu.tr \\ Orcid: 0000-0001-8969-6144
}

Date Received: 10.05.2019

Date Accepted: 11.06 .2019

Date Published: 22.07.2019

DOI: 10.17680/erciyesiletisim.562713

\begin{abstract}
As it is known that individuals spend most of their time with mass media, research on how the time spent on mass media affect their lives is widely available in the literature. Recently, in addition to this body of research, the time spent by individuals on social media and the effect of this time on the lives of individuals has begun to be examined. In the literature on this subject, it is also often questioned that how effective the time that individuals spend on social media, how much time they spend on social networks, or why they use social networks very often. One of the main aims of people to follow other people in social networks is to be stay informed. But at the same time, the same individuals use social networks to play games. Social networks that seek to offer different reasons to their members regarding the usage have reached their wishes with the help of these games they offer. In order to grasp why individuals choose to play games on social networks, this study examined why they prefer to produce in the virtual world, why they spend their leisure time on a game called FarmVille. FarmVille, one of the most played games in the world with the logic of virtual production, virtual distribution, and virtual consumption, was selected for this study and those who played this game were included in the axis of the study. The questionnaire was used as a measurement tool. It was found that $80 \%$ of the men and women among participants spent their two hours on the game daily. The time, which is expressed as the biggest problem of the modern day's man, was spent on games shows how much the individuals need to relax and to avoid the responsibilities and problems. When the results of the study were evaluated briefly; it was observed that the participants preferred the game mostly due to socialization, leisure time, relaxation, avoiding problems and responsibilities.
\end{abstract}

Keywords: Free Time, Leisure Time, Game, FarmVille, Virtual Manufacture, Virtual Consumption. 


\section{Giriş}

Hızla gelișen teknoloji insanların yaşamlarını da değiștirmektedir. Üretimin artmasıyla birlikte tüketimde aynı şekilde hızlanmış ve insanlar için zamanın verimli kullanılması büyük sorun olmaya başlamıştır. Bu durum zaman kavramının da yeniden değerlendirilmesine ve zamanın günlük yaşamda muhakkak kontrol altında tutulması gereken bir ölçü birimine dönüşmesine neden olmuştur. Her ne kadar teknolojik yenilikler hayatı, insanlar için daha kolay ve daha anlamlı kılmayı başarmış olsa da; bireylerin gün içerisindeki sorumluluklarına yenilerini de eklemiştir. Bu nedenle de modern çağda insanların en büyük endișe duydukları konu zaman olmuştur. Bilindiği üzere modern yaşam insana fazladan sorumluluklar yüklemekle kalmayıp onun çalışma süresini de artırmıştır. Günümüz insanı bu durum karşısında günün her zamanını efektif kullanmaya zorunlu kalmıştır. İnsanın sosyal ve iş yaşamındaki başarısında ya da başarısızlığında, onun zamanını nasıl kullandığı, neleri doğru, neleri ise yanlış yaptığı gibi sorularda bu kapsamda sıklıkla sorulmaya başlanmıştır. Dolayısıyla bu konunun ekseninde yapılan çalışmalar her geçen gün artmaktadır. Genellikle de bireylerin zamanlarının büyük bir kısmını kitle iletişim araçlarıyla geçirdikleri bilindiği için, kitle iletişim araçlarına ayırdıkları zamanın onların hayatlarını ne yönde etkilediğini konu edinen araștırmalar literatürde fazlasıyla bulunmaktadır.

Son zamanlarda ise bu araştırmalara ek olarak bireylerin sosyal medyaya ayırdıkları zamanı ve bu zamanın bireylerin yaşantısına etkisi de yeni yeni incelenmeye başlanmıştır. Bu konuyla ilgili literatüre bakıldığında sıklıkla bireylerin sosyal medyada geçirdikleri zamanın ne derece etkili olduğu, ne kadar süreyi sosyal ağlara ayırdıkları ya da sosyal ağları neden bu kadar sık kullandıkları ayrı ayrı sorgulanmaktadır. Bilindiği üzere sosyal ağlarda insanların diğer insanları takip etmelerinin temel amaçlarından birisi bir şeylerden haberdar olmaktır. Fakat aynı zamanda aynı bireyler sosyal ağları oyunlar oynamak içinde kullanmaktadır. Üyelerine farklı sebepler sunmanın yolunu arayan sosyal ağlar eğlence özelinde sundukları bu oyunlar ile isteklerine ulaşmış bulunmaktadır.

Çünkü sosyal ağlar üzerinden oynanan oyunlar zaman içerisinde çok fazla kullanıcı tarafindan tercih edilmektedir. Hatta Android, IOS ve diğer mobile işletim sistemleriyle desteklendiği için de neredeyse her zaman kullanıcısının elinin altında bulunmaktadır. Dolasıyla da kullanıcılar her boşluk bulduklarında oyunlara vakit ayırabilmektedir. Belki de bu yüzden Kellner'in $(2013,41)$ yeni iletişim teknolojilerinin sadece bilgi teknolojisi olmaktan çok daha fazlasını içerdiği eleştirisi önem kazanmaktadır. Neticede Kellner yeni iletişim teknolojilerinin gerek çalışma, gerekse de boş zaman uğraşlarını kuşatan ve onları baştan aşağı değiştiren eğlence, iletişim, multimedya, enformasyon ve eğitimin önemli unsurlarını içerdiğini söylemektedir. Ancak her ne kadar farklı unsurların bir araya geldiği kabul edilse de bunlar içerisinde eğlence diğerlerine göre daha fazla tercih edilmektedir. $\mathrm{Bu}$ bağlamda kullanıcısına başlıca zamanını eğlenceli geçirmeyi ve arkadaşlarıyla paylaşım içerisinde olmayı vaat eden oyunların neden tercih edildiği böylece anlaşılmaktadır. Eğlencenin hayatın merkezinde olmaya başlamasıyla birlikte oyun sektörünün büyüdüğü ve dünyada yaklaşık 1 milyarın üzerinde insanın çevrimiçi oyun oynadığı bilinmektedir (www.btk.gov.tr, 2018)

Yukarıda bahsedilen bilgiler doğrultusunda, bireylerin başlıca sosyal ağlarda neden oyun oynamayı tercih ettiklerini anlamaya yönelik hazırlanan bu çalışmada 
bireylerin, sanal dünyada üretim yapmayı neden tercih ettikleri, boş zamanlarını neden bu oyunla geçirdikleri incelenmiştir. Sanal üretim, sanal dağıtım ve sanal tüketim üzerine kurulu mantığıyla dünyada en fazla oynanan oyunlardan birisi olan FarmVille bu kapsamda çalışma için seçilmiş, bu oyunu oynayanlar çalışmanın eksenine dahil edilmiştir. Ayrıca çalışmada ölçme aracı olarak ankete başvurulmuştur. Dolayısıyla çalışmanın ilk bölümünde kuramsal bilgilere yer verilirken ikinci bölümde ise anket uygulamasından elde edilen istatistiki veriler IBM SPSS 24 programı aracılığıyla değerlendirilmiştir.

\section{Sanal Üretim, Sanal Tüketim}

Yaşamın temel iki değişmezi olarak karşımıza üretim ve tüketim çıkmaktadır. Bilindiği üzere her canlının hayatını sürdürebilmesi için aktif bir tüketici olma zorunluluğu bulunmaktadır. Ancak insanı bu süreçte diğer canlılardan ayıran temel faktör, tükettiği şeylerin üretimine katılmak zorunda olmasıdır. Ayrıca insan üretimine katıldığı tüm nesneleri çeşitli şekillerde test etmekte, hatta bir nesnenin kimi zaman milyonlarca kopyasını birebir aynısı gibi yapmak zorunda kalmaktadır. $\mathrm{Bu}$ nedenle de insan, üretim ve tüketim sürecinde temel aktör konumundadır. Yaşamının temel dayanak noktasını da kendisi dışındaki diğer bireylerin ürettiği şeyleri tüketmek ya da kendisinin tüketeceğinden fazlasını üretmek üzerine kurmuştur. Dolayısıyla üretimi zaman içerisinde çeşitlendirmiş, üretim süreçlerinde geliştirmeler yapmıştır. İnsanoğlunun her geçen gün artan nüfusu, küreselleşme ve teknolojik ilerlemeler bu durumun zorunlu nedenlerinden birisi olarak karşımıza çıkmaktadır. Özellikle de teknoloji alanında yaşanan gelişmeler üretim ve tüketimi farklı bir boyuta taşımıştır. Seri üretim modern yaşamın bir vazgeçilmezi olmakla kalmayıp, üretimi hızlandırmış, kusursuzlaștırmış ve artırmıştır. Bu noktada Marx'ın üzerinde durduğu temel kavramlardan birisi olan yabancılaşma kavramı, üretim süreci düşünüldügünde farklı bir boyut kazanmıştır. Bilindiği üzere Marx üretimdeki yabancılaşmayı işçi özelinden ele almaktadır. Ona göre üretimde işçinin ürüne yabancılaşması büyük önem arz etmektedir. Bilhassa sanayi devriminden sonra hızla artan makineleşme ve fabrikasyon, üretim bandındaki işçiyle ürettiği nesne arasındaki bağı azaltarak ikisi tarafı da birbirine yabancılaştırmıştır. Bu bağlamda da Marx işçinin ne kadar çok üretim yaparsa o kadar az tüketecek nesneye sahip olduğunu, ne kadar çok değer yaratırsa da o kadar çok değerden düştüğünü ve saygınlığının azaldığını ileri sürmüștür (Marx, 2013, 23). Aslında bir nevi "değersizleșme" olarak tanımlanabilecek bu süreçle birlikte birey insanoğlunun doğasında var olan ve sosyal yaşamla meşrulaşan olgusal kodlar özelindeki sabit değerleri yitirerek, yozlaşmaktadır (Durak ve İrğat, 2016, 78). Ancak bu yozlaşma başlangıçta sadece ürün ve işçi arasında gerçekleşiyor gibi görünse de; zaman içerisinde sosyal yaşamın her aşamasında kendisini göstermektedir. Baudrillard bu durumu "simülasyon" kavramı ile açıklamaktadır. Baudrillard'a $(2011,35)$ göre simülasyon en değersiz olguları bile içine alan, gerçeğin yerine almış modellerden oluşmaktadır. Aslında temel olan burada gerçekliğin yitirilmesi ve sanalda üretilenlerin gerçekliğin yerine ikame etmeleridir. Baudrillard'ın bir gerçeklik olarak algılanmak istenen görünüm diyerek açıkladığı ve simülakr terimiyle kavramsallaştırdığı bu durum, diğer bir ifadeyle gerçekliğin yitirilmesi olarak da bilinmektedir. Gerçekliğin yitirilmesiyle birlikte Marx'ın ürünle yabancılaşan bireyinin yerini, gerçeklikle yabancılaşan bireyler almaya başlamıştır. Bunda teknolojik gelişmelerle birlikte artan internet kullanımının rolünün büyük olduğu görülmektedir. Özellikle internet aracılığıyla artan sanal tüketimin hem ihtiyaçlar 
sistemini üreten, hem de onu yönlendiren bir hale bürünmüş olmasıyla birlikte tüketim malları da sanal düzenin bir parçası olmuştur (Ulutürk, 2017). Hatta Baudrillard (2006, 140-141) diyalektiğin vazgeçilmez öğesi olarak nitelendirdiği "öteki"nin bile artık günümüzde gerçeklikte yok edildiğini, kusursuz bir cinayete kurban gittiğini bunun yerine artık üretimin nesnesi olan sanal bir ötekinin kurulduğunu belirtmektedir. Dolayısıyla üretimin bu derece sanallaşmış olması tüketiminde aynı derece sanallaşmasını doğurmaktadır. Çünkü sanal bir biçimde yapılan üretimin tüketimi de yine sanal olarak gerçekleşmektedir. Bu bağlamda bilgisayar, konsol ve mobil araçlarla oynanan oyunlar, onlarda yaratılan sanal dünyalar ve buralarda geçirilen zaman büyük önem arz etmektedir. Aslında Huizinga'nın oyunun "boş zaman" içerisinde gerçekleştirilmesi gereken bir faaliyet olduğunu savunması belki de buradan gelmektedir. Çünkü Huizinga'ya (2006, 2425) göre oyun her şeyden önce gönüllü bir eylemdir ve emirlere bağlı değildir. $\mathrm{Bu}$ nedenle de oyun her ne olursa olsun insan ve sorumlu yetişkin için, istediği an ihmal edebileceği bir faaliyet olarak görülmelidir. Ancak durum bu şekilde ilerlememektedir. Oyun gün içerisinde insanın asıl sorumluluklarını ihmal ettiği, hatta işlem sırası bekleyen insanlar varken bireylerin fütursuzca onları yok sayarak, işinden kopup uğraştığı bir eğlence aracına dönüşmüştür. Araştırmacılar içinde yoğun bir şekilde bireyler tarafından fazlaca tercih edilerek oynanan oyunların, bu bireylerin gündelik yaşamları üzerindeki etkileri incelenmesi gereken yeni bir alandır. Çünkü araştırmacılar için gün içerisinde çoğunlukla sanal dünyada haz dışında bir kazanımları olmayan bireylerin gerçek dünyadaki işlerinden ve sorumluklarından kaçarak bu dünyalara kendilerini hapsetmeleri normal bir durum olarak görülmemektedir. Oyunun insanoğlunun yeryüzündeki ilk adımlarıyla birlikte ortaya çıkan bir kavram olduğu bilinmektedir Fakat oyun buna rağmen her çağda eleştirilen bir kavram olmuştur. Tarihsel süreç incelendiğinde ise hiçbir oyun günümüzdeki gibi insanı gerçek yaşamdan bu kadar uzaklaştırmamıştır. Gerçek yaşamdaki sorumluluklarını sanal dünyadaki kazanımlar için göz ardı etmemiştir. Dolayısıyla burada temel sorun bireylerin oyuna ne derece bağlandıkları kadar sanal dünyada yaptıkları üretim ve tüketimin onlara ne kattığı olmalıdır. Kabul edilmelidir ki insanların gündelik yaşamlarının bir parçası olan oyunlar, maddi ve manevi olarak da tüketim araçlarıdır. Farklı cinsiyetlerden, yaşlardan hatta milletlerden insan gruplarının gündelik yaşamlarının bir kısmında etkileşimde bulundukları ve zaman geçirdikleri mecralar olmalarından ötürü büyük de önem taşımaktadır. Fakat bilindiği üzere çeşitli gerekçelerle farklı yaştan ve farklı kültürden insanların oyunlara ayırdıkları süreler ile bu sürelerin anlamları da değişiklik göstermektedir (Binark ve Bayraktutan-Sütçü, 2008, 35). Hatta oyunları oynama biçimleri, oyunlardaki tüketim şekilleri de farklılık göstermektedir. Bu denli yoğun parametrelerin olduğu oyunlarda insanların yaptıkları üretimler ve tüketimler kadar oyunlarla geçirdikleri zamanlarında farklı anlamlar içerdiği bilinmektedir. Ancak dikkat edilmesi gereken nokta burada; insanların oyunlarda yaptıkları üretimlerin ve tüketimlerin gerçek yaşantılarında ne derece etkili olduğudur. Bilindiği üzere sanayi işletmelerinin ilk üretimleri sanal ortamlarda hazırlanan özel simülasyonlarla gerçekleștirilmektedir. Bu simülasyonlar aracılığıyla hem üretim bantları hem de üretim süreçleri kontrol edilmekte, bina yerleşimleri ve ürün tasarımları da yine bu sanal ortamlarda düzenlenmektedir. Hatta büyük kapsamlı ev projeleri de ilk olarak sanal mecralarda üretilmekte, orada alıcılara tanıtılmakta ve satışları bu tanıtımlar üzerinden gerçekleşmektedir. Sanal olarak 
üretilen ürünler başlangıçta burada tüketilmek sonrasında ise gerçek hayatta karşıllı bulmaktadır. Ancak bilgisayar oyunlarında ise durum genellikle çok farklıdır. Çünkü sanal bir dünyada yaratılan imgeler, kahramanlar, ürünler hatta kurulan dünyaların, bunlar için harcanan zamanın kısacası bunların üretimlerinin karşıllı̆ı sadece sanal dünyada kalmakta ve çoğu zaman gerçek dünyada bir karşılık bulmamaktadır. Dolayısıyla insanlara verdiği kazanım sadece haz olarak kalmaktadır. Bu nedenle de sanal bir üretimin karşılığı olan sanal tüketimin insan hayatının birinci önceliği olarak görülmesi, buna bağlanılması en başta Maslow'un yllar önce söylediği ihtiyaçlar hiyerarşisinin de önüne geçmektedir. İnsanlar gerçek yaşamda rahatlıkla birçok kazanım ve deneyim elde edecekleri boş zamanlarını sanal ortamlarda değerlendirmektedirler. $\mathrm{Bu}$ durum insan gelişiminin ve yaşantısının bir parçası olan boş zaman ve serbest zaman kavramlarının da yeniden gözden geçirilmesini gerektirmektedir. Çünkü oyunlarda geçirilen boş zamanın, bir serbest zaman etkinliği mi olduğu sorusu bile aslında cevaplanması gereken bir soru olarak durmaktadır. Bilindiği üzere serbest zaman boş zamanın içinde insanın gelişimi için kullandığı, bir aktivite olarak kısaca açıklanmaktadır. Bu zaman dilimi içerisinde insan fiziksel ihtiyaçlarını da karşılayabildiği gibi, sosyal, duygusal motivasyonunu kişisel gelişimini etkileyici, kabiliyetlerini artırıcı yeni kazanımlarda elde edilmektedir. Örneğin yemek yemek sadece açlığın bastırılması özelinde ise boş zaman etkinliği olarak, arkadaşlarla sohbet ederek duygusal ve sosyal bir etkinlik olarak değerlendiriliyorsa serbest zaman etkinliği olarak değerlendirilirken, oyunların boş zaman ya da serbest zaman etkinliği mi olduğu sorusu da yine cevap beklemektedir. Dolayısıyla oyunlarda geçirilen zamanı öncelikle boş zaman kavramı özelinde değerlendirmek gerekmektedir.

\section{Oyunlarda Yitirilen Boş Zaman}

Gündelik yaşamın programlanmasını daha verimli bir şekilde kullanılmasına yardımcı olan zaman kavramı üzerine birçok düşünür kafa yormuş farklı yaklaşımlar sergilemiştir. Örneğin Aristo zamanı bir devinim olarak görmekteyken, zamanın bir ruhu olması gerektiğinin de altını çizmektedir. Bu bağlamda zaman Aristo için mutlak anlamda sayıyla ölçülen bir devinim değildir. Aksine süreklilik arz etmektedir. Dolayısıyla farklı olaylar an itibariyle, birlikte gerçekleştiklerinde hızları ne olursa olsun zamandaş olarak değerlendirilirler. Bundan dolayı zaman her yerde aynı ve tek olandır. Hatta zaman bir tür yer değiştirmenin ölçüsüdür (Aristoteles, 1996, 17-19). Konuya daha farklı yaklaşan Heiddegger ise zamanı öncelikle kesintisizlikler dizisi olarak görmektedir. Bu nedenle de zamanın akmaya devam eden, sonu olan bir şey olduğunu savunmaktadır. Ayrıca Heiddegger zamanın incelenmesinde ortaya yine aynı sonucun çıkacağını söylemektedir. Ona göre "şimdi" yi parçalara ayırıp incelediğimizde ortaya yeni bir "şimdi" çıkmaktadır. Ancak bu ortaya çıkan özü itibariyle tarihlendirilebilen bir şey olup, yine özü gereği ya bir șeylerin zamanıdır ya da değildir. Dolayısıyla zaman kavramı Heiddeger (2006, 439-449-450) için duruma göre bir son içeren, tarihsellik arz eden ve bu bağlamda bölümlenebilen bir kavram olarak durmakta ve yalnızca yeni bir insanın yaşama dâhil olduğu andaki gibi, sadece kamusal zaman olarak bilinebilmektedir. Zaman üzerine çalışan bir diğer düşünür olan Levinas $(2005,106)$ ise zamanı insanlar arası ilişkinin tarihsel bir süreçte değerlendirilmesi olarak görmektedir. Genel olarak düşünüldüğünde ise zaman insanların yaşantılarını programlamaya yarayan bir ölçü birimidir. Ancak her ölçü birimi gibi zamanda araştırmacılar tarafından bölümlenmekte ve öyle incelenmektedir. Özellikle de bireyin gün içerisindeki 
davranışlarını ölçmek ve gelişimini takip etmek için araştırmacılar zaman kavramını "serbest (leisure)" ve "boş(free)" olmak üzere iki kategoriye ayırmaktadır. Serbest zaman üzerine çalışan araştırmacılar terimin etimolojik kökenlerini Latincedeki "licere" ve Fransızcadaki "loisir" kelimelerine dayandırmaktadır (McLean, Hurd, ve Rogers, 2008, 33). Murphy'e göreyse (1974, 72 Aktaran Veal, 1992, 5) serbest zamanı iş ve temel ihtiyaçlar dışında kalan zaman olarak tanımlamaktadır. Bu nedenle de serbest zaman insanların boş zamanlarının içerisinde olan farklı bir zaman dilimi kapsamaktadır. Aslında belki de burada dikkat çekilmesi gereken konu Wilensky'nin yaklaşımı olacaktır. Çünkü Wilensky modern toplumun genel olarak iş ve ev arasına odaklanmış insanlardan oluştuğunu söylemektedir. Ancak Wilensky'nin burada işaret ettiği nokta bireylerin işten eve geldiklerinde sosyal ortamlarla değil de yalnızca televizyonla vakit geçirmeleridir. Çünkü ona göre televizyonla bu derece yoğun zaman geçiren bireyler zaman içerisinde toplumla yabancılaşmaktadır. Bundan dolayı da ona göre serbest zaman bireyler üzerinde ödünleştirici ve yabancılaştırıcı etkisi olan bir kavram olarak ele alınmalıdır. Çünkü bu zaman dilimi bireye herhangi bir katkı sağlamamaktadır (Wilensky, 1960, 559 - 560). Aksine tembelleștirmekte ve yabancılaștırmaktadır. Bu düşünceye göre serbest zaman etkinliklerinin bireyin davranışlarına, yaratıcılığına ve çevresine sağlayacağı faydaların olması gerekmektedir.

Serbest zaman kavramı gibi araştırmacıların üzerinde ısrarla durdukları bir diğer kavram olan "boş (free time) zaman" kavramıdır. Boş zaman kaba bir tanımlamayla bireyin bir takım ihtiyaçlarını karşılamak ya da bazı zorunluluklarını yerine getirmek için kullandığı zaman dilimi olarak karşımıza çıkmaktadır. Bilhassa bu durumda boş zamanın irdelenmesi gerekmektedir. Bazılarına göre boş zaman olarak adlandırılan bu zaman diliminde bireyler hiçbir faaliyet yapmamaktadır(Mieczkowski, 1990, 9). Ancak hiç bir şey yapılmamak kısmı biraz muğlak bir ifade olarak durmaktadır. Örneğin uyumak ya da yemek yemek bireyin etkin olarak bir şey üretmediği, bu nedenle bir şey yapmadığı bir durum gibi algılanmasına rağmen aslında karşılanması gereken temel ihtiyaçlardır. Bundan dolayıda Aydoğan'ın boş zamanı “bireyin sağlı̆ı ve yaşamı için gerekli olan yemek, uyumak gibi kişisel gereksinimleri, ailesi, toplumu ve ülkesiyle ilgili yükümlülüklerin yapıldığı zaman" olarak tanımlaması dikkat çekmektedir. Yine boş zaman üzerine çalışan Tezcan'ın bu konuda yaklaşımı da önem taşımaktadır. Tezcan, Boş Zamanlar Sosyolojisi isimli çalışmasında boş zamanın bireylerin çalışma saatlerinin dişında kalan bir zaman olduğunun altını çizmektedir. Ayrıca bu zaman dilimini fizyolojik gereksinimler, çalışma dışı zorunluluklar ve boş zaman olmak üzere üç gruptan oluşmaktadırlar. Bu bağlamda Tezcan fizyolojik ihtiyaçları özellikle çalışma dışı zamanda gerçekleştirilen birer faaliyet görmektedir. Ona göre yemek yeme, uyuma gibi faaliyetler ise boş zaman içinde dahi olsa gerçek anlamda bir boş zaman faaliyeti değildir. Çünkü şayet bir birey sadece acıktığı için yemek yiyorsa ve bunu tek başına yapıyorsa bu bir gerekliliktir. Ancak bir lokantaya gidiyor, hatta buna vakit ayırarak orada arkadaşlarıyla buluşuyor, onlarla birlikte bu faaliyeti gerçekleștiriyorsa bu bir boş zaman faaliyetidir (Tezcan, 1993, 9-10). Bu noktada iki görüşün önem taşıdığı görülmektedir. Bunlardan birincisi Wilensky'nin serbest zaman faaliyetlerinin yabancılaştırma etkisi aynı işten gelen bireyin televizyon izleyerek çevresiyle ve toplumla yabancılaşması gibi bir etkisi olduğu görüşüdür. Diğeri ise Mieczkowski'nin boş zamanı hiçbir şeyin yapılmadığı üretilmediği bir zaman olarak nitelendirmesidir. Temel sorun tam burada ortaya çıkmaktadır. Çünkü bir faaliyetin serbest zaman olabilmesi için 
onun fiziksel ihtiyaçların dışında olması ve belki de bireye belli bir katkı sağlaması gerekmektedir. Boş zaman faaliyeti olabilmesi için ise bireyin fiziksel ihtiyaçlarının ya da zorunlu gereksinimlerinin karşılanmasına ayrılan süre olması gerekmektedir. Dolayısıyla serbest zamanda bir üretim ya da bir faaliyet içerisinde olma zorunluğu varken, boş zamanda bir gereksinim karşılamak ya da bir zorunluluğu yerine getirmek ve bunun içinde olmak gerekmektedir. Ancak bilgisayar, konsol ya da mobil oyunlarında ise durum farklılık göstermektedir. Çünkü gerçek bir üretim ya da tüketimin yapılmadığı, bireyin gelişimine katkısının her geçen gün tartışıldığı bu dijital oyunlara ayrılan süre sıklıkla tartışılmaktadır. Özellikle bu oyunların yarattığı bağımlılık etkisi sıklıkla dile getirilmektedir. Ayrıca dijital oyunların başta çocuklar olmak üzere bireylerin yaratıcılığı üzerindeki etkisinin olumsuz olduğu savunulmaktadır (Dilci, 2015). Fakat her ne kadar eleștirilirse eleştirilsin, olumsuz etkileri konusunda araştırma yapılsın değişmeyen bir şey varsa o da modern çağda insanların oyun oynamaktan geri durmadığı gerçeğidir. Bilgi Teknolojileri ve İletişim Kurumu'nun (BTK) dünya üzerinde bir milyardan fazla insanın dijital oyun oynadığını açıklaması da bu durumu kanıtlamaktadır (www.btk.gov.tr, 2018). Hatta çevrimiçi olmayan oyuncu sayısı da eklendiğinde rakamların büyüyeceği de bir gerçektir ve bu da aslında bir sorun olarak görülememelidir. Ancak ne zamanki oyun Huizinga'nın da dediği gibi insanların hayatlarının amacına dönüşürse o zaman ortaya bir sorun çıkacaktır. Çünkü oyun aslında insanın ruhuna dinlenme ya da gevşeme sağlayan bir ilaç gibi, çalışmanın stresinden kaçmak için başvurulan bir araç olarak değerlendirilmelidir (Huizinga, 2006, 205). Bu nedenle de insanların boş zamanlarında oyunlara yönelerek eğlenmeleri de normal bir durum olarak görülmektedir. Ancak burada sorun olan şey aynı Huizinga'nın da altını çizdiği gibi oyunun artık amaç haline dönüşmesi ve insanların gerçek yaşamdan koparak Baudrillard'ın da sıklıkla bahsettiği sanal dünyaya kendilerini mahkûm etmesidir. Ancak bu hapsoluştan kimi zaman bireyler haberdar değildir ve burada yaptıkları faaliyetleri, üretimleri ya da yaşadıkları deneyimleri gerçek dünyaya tercih edebilmektedirler. Bu nedenle de oyunların bir serbest zaman etkinliği mi yoksa bir boş zaman değerlendirme şekli mi olduğu da tartışılmaktadır. Örneğin Nielsen Araştırma Şirketi'nin tüm dünyada yaptığı araştırmaya göre modern çağın vazgeçilmez bir etkinliği olarak oyunlar karşımıza çıkmaktadır. Ayrıca insanlar gün içerisinde serbest zamanlarının en az \%10'unu oyunlara ayırmaktadır (www. digitalstrategyconsulting.com, 2016). Günlük yaşantı içerisinde büyük bir zaman dilimini kapsayan bu süre aslında sorgulanabilir bir durumdur. Ancak bilindiği üzere oyunun en basit biçimlerinde ve hatta hayatın içinde bile, olabildiğince bedensel bir olgudan veya fizyolojik olarak belirlenen psişik bir tepkiden daha fazla bir şey içermesi insanlar tarafından tercih edilme sebebi olarak değerlendirilmektedir. Ya da diğer bir ifadeyle anlam bakımından zengin olan oyun; bireyin yaşantısındaki gereksinimlerini doğrudan aşan ve insanın davranışlarına mana katan bağımsız bir öğe olarak görülmekte, bu nedenle de sevilmektedir (Huizinga, 2006, 17). Dolasıyla da insanlar sadece zevk aldıkları için değil aynı zamanda hayatlarına bir anlam kattığı için ya da farklı bir amaç sunduğu içinde oyunu tercih etmektedir. Ancak burada sorgulanması gereken şey serbest ya da boş hangi zaman türü olursa olsun bunların ne kadarının oyunlarda geçirildiğidir. Diğer bir yaklaşımla ise bireylerin oyunlarda yaptıkları faaliyetlerin gerçekte onlara ne sunduğu ya da onlara ne kazandırdığıdır. Bu kapsamda yapılan çalışmada ise insanların oyunları neden tercih ettikleri üzerine yoğunlaşılmıştır. Özellikle de üretim ve tüketim 
özelinde gerçekleșen oyunlardan birisi olan FarmVille seçilerek, çalışmaya katılan bireylere bu oyunu neden oynadıkları, nereden bu oyuna erișim sağladıkları gibi sorulara yöneltilmiştir.

\section{Araştırmanın Amacı}

Üretim ve tüketim dengesi hem ekolojik hem de ekonomik veriler açısından büyük önem arz etmektedir. Canlılar dünyasının temeli de üretim ve tüketim üzerine kurulmuştur. Gelişen teknoloji, artan nüfus, ekonomik imkânlar, yaşam tarzı, sosyal çevre gibi birçok şey insanların üretim ve tüketim alışkanlıklarında yıllardır belirleyici konumda bulunmaktadır. Ancak zamanın gelişimi üretimin serileşmesi canlıların tüketim alışkanlıklarını ve zorunluluklarını da değiştirmiştir. Özellikle modern çağda oyunlar üzerinden kurulan dünyalarda insanlar sanal üretimler ve tüketimler yapmaya gerçek hayatta arzuladıkları fakat yapamadıkları şeyleri yapmaya, zamanlarını bu mecralarda değerlendirmeye alışmışlardır. Ancak bu mecralardaki üretimlerin ve tüketimlerin ise gerçek yaşamda çoğu zaman bir karşılığı bulunmamaktadır. Dolayısıyla araştırmada başlıca bu konu üzerine yoğunlaşılmış olup, insanların sanal üretim ve tüketimin yoğun olarak yapıldığı FarmVille oyununu neden tercih ettikleri, burada neden bu denli vakit geçirmeyi gerçek zamana yeğlediklerinin saptanması amacına yönelik olarak yapılmıştır.

\section{Araștırma Soruları}

FarmVille oyununu oynayan bireylerin, bu oyunu oynama amaçları ve motivasyon düzeylerini ölçmek amacıyla yapılan araştırmada şu sorulara cevaplar aranmıștır.

Araştırma Sorusu 1: FarmVille kullanım motivasyonları ile faktörler arasında nasıl bir ilişki vardır?

Araştırma Sorusu 2: FarmVille oyunu ile bireylerin cinsiyetleri arasında herhangi bir ilişki var mıdır?

Araştırma Sorusu 3: FarmVille oynayan bireylerin oyunu oynamada etkili olan faktörler ve bireylerin eğitim düzeyleri arasında nasıl bir ilişki vardır?

Araştırma Sorusu 4: FarmVille oynayan bireylerin oyunu oynamada etkili olan faktörler ile meslekleri arasında bir ilişki var mıdır?

Araştırma Sorusu 5: FarmVille oynayan bireylerin oyunu oynama süreleri ile cinsiyetleri arasında bir ilişki var mıdır?

Araştırma Sorusu 6: Bireylerin internet erişim yerleri ile FarmVille kullanım süreleri arasındaki herhangi bir ilişki var mıdır?

Araştırma Sorusu 7: FarmVille oyununda geçirilen süre ile FarmVille oyununu oynamaya iten faktörler arasındaki nasıl bir ilişki vardır?

\section{Araştırmanın Yöntemi}

Sosyal Paylaşım Sitesi Facebook üzerinden oynanan FarmVille oyununu oynayan bireylerin motivasyonlarını araştırmaya yönelik olan bu çalışmaya tüm Türkiye genelinde 406 kişi katılmıştır. Araştırma soruları internet üzerinden Online Anket sitesi aracılığıla FarmVille oynayan bireylere elektronik posta yoluyla gönderilmiş ve buradan toplanan cevaplar IBM SPSS 24 aracılığıyla analiz edilmiştir.

\section{Araştırmanın Evren ve Örneklemi}

Araştırmanın evrenini FarmVille oyununu oynayan bireyler oluşturmaktadır. Araştırmanın örneklemi ise FarmVille oyununu aktif olarak oynadıkları bilinen 
ve aynı zamanda gönderilen anketi dolduran bireylerden oluşturulmuştur. Örneklem dahilinde araştırmaya katılan bireylere ilişkin demografik bilgilere çalışma içinde yer verilmiştir.

\section{Araştırmanın Veri Toplama Araçları}

Araştırmanın evrenini Türkiye'de Facebook.com sitesi üzerinden FarmVille oyununu oynayanlar oluşturmaktadır. Araştırmanın evreni oluşturulurken, evrenin sonsuz küme olması nedeniyle Uzgören'in (2012, s. 182) çalışmasında 100.000 ve üzeri ana kütlenin olması durumunda 384 gerekli örneklem birim sayısının alınması gerektiği belirtilmiştir. Bu nedenle araştırmanın örneklemi Türkiye'de Facebook.com üzerinden FarmVille oyununu oynayan bireyler olarak belirlenmiştir. Bireylerin motivasyonlarını araştırmaya yönelik olan bu çalışmaya tüm Türkiye genelinde 406 kişi katılmıştır. Araştırma soruları internet üzerinden Online Anket sitesi aracılığıyla FarmVille oynayan bireylere elektronik posta yoluyla gönderilmiş ve buradan toplanan cevaplar IBM SPSS 24 aracılığıyla analiz edilmiştir.

Anket iki bölümden oluşmaktadır. Birinci bölümde FarmVille oynama motivasyonlarını ölçmek için 5’li Likert tekniğine göre hazırlanan sorular sorulmuştur. Anketin ikinci bölümündeki sorular ise, ankete katılan bireylerin demografik özelliklerini belirlemek amacıyla sorulan sorulardan oluşmaktadır.

Tablo 1: Çalıșmada Kullanılan Ölçeğin Faktör Analizine Uygunluğuna Yönelik Veriler

\begin{tabular}{|l|c|c|}
\hline Kaiser-Mayer-Olkin (KM0)/Örneklem Ölçüm Değer Yeterliliği &, 951 \\
\hline \multirow{2}{*}{ Barlett Testi } & Ki-Kare & 6909,92 \\
\cline { 2 - 3 } & Df & 378 \\
\hline Cronbach's Alpha &, 953 \\
\hline p=,000 & \multicolumn{2}{|l}{} \\
\hline
\end{tabular}

Yapılan bir çalışmada elde edilen verilerin faktör analizine uygun olup olmadığı, genellikle KMO değeri üzerinden değerlendirilir (Altunışık, Coşkun , Bayraktaroğlu ve Yıldırım, 2007, 293). FarmVille oyununa yönelik yapılan anketin incelemesinde KMO değerinin 0,951 olduğu saptanmıștır. Dolayısıyla anket sonucunda elde edilen veriler, faktör analizi için uygundur. Yine araştırmalarda sıklıkla güvenirlilik analizine de başvurulmaktadır. Cronbach Alpha $(a)$ sayısı olarak da bilinen bu değer 0 ile 1 arası aralığında yer almaktadır. Cronbach Alpha değerinin en az 0,7 olması araştırmanın güvernirliği için kabul edilmektedir. Yapılan bu araştırmada Cronbach Alpha değeri 0.953 çıkmıştır. Dolayısıyla araştırma güvenirliğinin yüksek düzeyde olduğu saptanmıştır.

\section{Araştırmada Kullanılan Testler}

Araştırmada bireylerin demografik özelliklerinin belirlenmesi amacıyla yüzde ve frekans analizi yapılmıştır. Ayrıca bireylerin FarmVille ile ilgili motivasyonlarının belirlenmesine yönelik faktör analizi, birbirleriyle olan ilişkilerini belirleyebilmek için de Anavo, T-Testi, Çapraz Tablo ve Korelasyon analizleri yapılmıştır.

\section{Araştırmanın Bulguları}

Facebook üzerinden FarmVille oyununu oynayan bireylerin motivasyonlarını ölçmek amacıyla yapılan bu çalışmaya 406 kişi katılmıştır. Bu katılımcıların \% 54,2'si erkek, \% 45,8'i kadındır ve bunların \%21,7'si evli iken, \%78,3'ü bekârdır. Araştırmaya katılan bireylerin \%33,7'sinin aylık geliri 500 TL'den az, \% 36,7'si 
501 ila 1500 TL arasında aylık gelire sahip, \% 27,5’i ise 1500 TL'nin üzerinde gelire sahiptir.

Araştırmaya katılan bireylerin \%53,9'u büyükşehirde, \%35,2'si şehirde, \%7,6'sı ilçede, \%,3,2'si köyde yaşamaktadırlar. FarmVille oyununu oynayan bireylerin \%79,8'inin üniversite mezunu olduğu ve yaşlarının büyük çoğunluğunun 17 - 30 yaş arasında olduğu saptanmıştır. Araştırmaya katılan bireylerin \%67'sinin öğrenci, \%9,6'sı memur, \%5,2'sinin ev hanımı, 18,2'sinin ise işçi, çiftçi, emekli ve serbest meslek sahibi olduğu belirlenmiştir.

Tablo 2: Araştırmaya Katılanlara İlişkin Demografik Özellikler

\begin{tabular}{|c|c|c|c|c|c|c|c|}
\hline \multicolumn{2}{|c|}{ Demografik Özellikler } & \multirow{2}{*}{$\begin{array}{c}\begin{array}{c}\text { Frekans } \\
\text { (f) }\end{array} \\
220 \\
\end{array}$} & \multirow{2}{*}{$\begin{array}{c}\begin{array}{c}\text { Yüzde } \\
\text { (\%) }\end{array} \\
54,2 \\
\end{array}$} & \multicolumn{2}{|c|}{ Demografik Özellikler } & \multirow{2}{*}{$\begin{array}{c}\begin{array}{c}\text { Frekans } \\
\text { (f) }\end{array} \\
318\end{array}$} & \multirow{2}{*}{$\begin{array}{c}\begin{array}{c}\text { Yüzde } \\
\text { (\%) }\end{array} \\
78,3\end{array}$} \\
\hline \multirow{3}{*}{ Cinsiyet } & Erkek & & & \multirow{3}{*}{$\begin{array}{l}\text { Medeni } \\
\text { Durum }\end{array}$} & Bekar & & \\
\hline & Kadın & 186 & 45,8 & & Evli & 89 & 21,7 \\
\hline & Toplam & 406 & 100 & & Toplam & 406 & 100 \\
\hline \multirow{7}{*}{ Aylık Gelir } & $\begin{array}{l}\text { Demografik } \\
\text { Özellikler }\end{array}$ & $\begin{array}{l}\text { Frekans } \\
\text { (f) }\end{array}$ & $\begin{array}{c}\text { Yüzde } \\
\text { (\%) }\end{array}$ & \multirow{7}{*}{ Yaş Aralığı } & 17 - 23 Yaş & 253 & 63,7 \\
\hline & $\begin{array}{l}500 \text { TL ve } \\
\text { Daha az }\end{array}$ & 137 & 33,7 & & $24-30$ Yaş & 80 & 19,7 \\
\hline & $\begin{array}{l}501 \mathrm{TL}- \\
1000 \mathrm{TL}\end{array}$ & 107 & 26,4 & & $31-37$ Yaş & 36 & 8,9 \\
\hline & $\begin{array}{l}1001 \mathrm{TL}- \\
1500 \mathrm{TL}\end{array}$ & 50 & 12,3 & & 38 - 44 Yaş & 16 & 3,9 \\
\hline & $\begin{array}{l}1501 \mathrm{TL}- \\
2000 \mathrm{TL}\end{array}$ & 43 & 10,6 & & $\begin{array}{l}45 \text { yaş ve } \\
\text { Üzeri }\end{array}$ & 21 & 5,2 \\
\hline & $\begin{array}{l}2001 \mathrm{TL} \\
\text { ve üzeri }\end{array}$ & 69 & 16,9 & & Toplam & 406 & 100 \\
\hline & Total & 406 & 100 & & & & \\
\hline \multirow{13}{*}{ Mesleğiniz } & Mesleğiniz & $\begin{array}{l}\text { Frekans } \\
\text { (f) }\end{array}$ & $\begin{array}{c}\text { Yüzde } \\
\text { (\%) }\end{array}$ & \multirow{6}{*}{$\begin{array}{l}\text { Yaşam } \\
\text { Yerleri }\end{array}$} & $\begin{array}{l}\text { Yaşam } \\
\text { Yerleri }\end{array}$ & $\begin{array}{l}\text { Frekans } \\
\text { (f) }\end{array}$ & $\begin{array}{c}\text { Yüzde } \\
(\%)\end{array}$ \\
\hline & Öğrenci & 272 & 67 & & Büyükşehir & 219 & 53,9 \\
\hline & Memur & 39 & 9,6 & & Şehir & 143 & 35,2 \\
\hline & İşçi & 32 & 7,9 & & İlçe & 31 & 7,6 \\
\hline & \multirow{2}{*}{$\begin{array}{l}\text { Serbest } \\
\text { Meslek }\end{array}$} & \multirow{2}{*}{33} & \multirow{2}{*}{8,1} & & Köy & 13 & 3,2 \\
\hline & & & & & Toplam & 406 & 100 \\
\hline & Çiftçi & 2 & 0,5 & \multirow{7}{*}{$\begin{array}{l}\text { Eğitim } \\
\text { Durumunuz }\end{array}$} & $\begin{array}{l}\text { Eğitim } \\
\text { Durumunuz }\end{array}$ & $\begin{array}{l}\text { Frekans } \\
\text { (f) }\end{array}$ & $\begin{array}{c}\text { Yüzde } \\
\text { (\%) }\end{array}$ \\
\hline & \multirow{2}{*}{ Emekli } & \multirow{2}{*}{7} & \multirow{2}{*}{1,7} & & İlkokul & 3 & 0,7 \\
\hline & & & & & Ortaokul & 14 & 3,4 \\
\hline & \multirow{2}{*}{ Ev Hanımı } & \multirow{2}{*}{21} & \multirow{2}{*}{5,2} & & Lise & 65 & 16 \\
\hline & & & & & Üniversite & 310 & 76,4 \\
\hline & \multirow{2}{*}{ Toplam } & \multirow{2}{*}{406} & \multirow{2}{*}{100} & & Lisansüstü & 14 & 3,4 \\
\hline & & & & & Toplam & 406 & 100 \\
\hline
\end{tabular}


Tablo 3: Araștırmanın Faktör Yükleri

\begin{tabular}{|c|c|c|c|c|c|}
\hline Faktörler & FarmVille Oynuyorum Çünkü & $\bar{X}$ & SD & $\begin{array}{c}\text { Faktör } \\
\text { Yüklemesi }\end{array}$ & Güvenirlilik \\
\hline \multirow{9}{*}{$\begin{array}{l}\text { Eğlence ve } \\
\text { Kolaylık }\end{array}$} & $\begin{array}{l}\text { Arkadaşlarıma puan almalarında } \\
\text { yardım edebiliyorum }\end{array}$ & 3,75 & 1,288 & ,725 & \multirow{9}{*}{,921 } \\
\hline & Şiddet içermeyen eğlenceli bir oyun & 3,50 & 1,207 & ,717 & \\
\hline & Arkadaşlarım da oynuyor & 3,74 & 1,146 &, 715 & \\
\hline & Sürekli güncelleniyor & 3,42 & 1,206 & ,712 & \\
\hline & Çiftliğimi kendim tasarlayabiliyorum & 3,91 & 1,201 & 671 & \\
\hline & Sıkılı̆̆ımda vakit geçiriyorum & 3,87 & 1,148 & ,661 & \\
\hline & Eğleniyorum & 3,80 & 1,197 & ,656 & \\
\hline & Bu oyunu oynamak hoşuma gidiyor & 3,62 & 1,243 & ,605 & \\
\hline & $\begin{array}{l}\text { Diğer oyunlara kıyasla } \\
\text { daha zevkli buluyorum }\end{array}$ & 3,25 & 1,298 &, 548 & \\
\hline \multirow{8}{*}{$\begin{array}{l}\text { Rahatlama } \\
\text { ve Kaçış }\end{array}$} & Dinlenmeme yardımcı oluyor & 3,07 & 1,325 & ,852 & \multirow{8}{*}{,887 } \\
\hline & Rahatlamama yardımcı oluyor & 3,26 & 1,326 & ,833 & \\
\hline & $\begin{array}{l}\text { Boş zamanlarımı değerlendirmeme } \\
\text { yardımcı oluyor }\end{array}$ & 3,23 & 1,356 & ,631 & \\
\hline & Beni yormuyor & 3,31 & 1,297 &, 572 & \\
\hline & Sorunlarımdan uzaklaşıyorum & 3,21 & 1,359 &, 549 & \\
\hline & $\begin{array}{l}\text { Şehir hayatının stresinden } \\
\text { uzaklaşabiliyorum }\end{array}$ & 3,08 & 1,373 &, 538 & \\
\hline & $\begin{array}{l}\text { Hedefe ulaşıyorum (oyunu } \\
\text { sonuçlandırmak / tamamlamak) }\end{array}$ & 3,43 & 1,338 &, 536 & \\
\hline & Arkadaşlarımla vakit geçiriyorum & 2,74 & 1,298 & 473 & \\
\hline \multirow{7}{*}{$\begin{array}{l}\text { Boş Zamanı } \\
\text { Değerlendirme } \\
\text { ve Rekabet }\end{array}$} & Yapacak başka bir işim yok & 2,64 & 1,351 & ,730 & \multirow{7}{*}{842} \\
\hline & $\begin{array}{l}\text { Gün içinde yapacak } \\
\text { başka bir işim yok }\end{array}$ & 2,50 & 1,344 &, 713 & \\
\hline & Yalnızlığımı gideriyor & 2,89 & 1,367 & ,691 & \\
\hline & \begin{tabular}{|l|} 
Hırsı tetikliyor \\
\end{tabular} & 3,33 & 1,352 &, 560 & \\
\hline & Sorumluluk yüklüyor & 3,08 & 1,386 &, 534 & \\
\hline & Satın alma duygumu tatmin ediyor & 2,67 & 1,362 &, 520 & \\
\hline & Rekabet duygusu oluşturuyor & 3,29 & 1,399 & ,454 & \\
\hline
\end{tabular}

Katılımcıların FarmVille kullanım motivasyonlarını belirlemek amacıyla Likert ölçeğine göre sorulan 24 soruya verilen cevaplar doğrultusunda faktör analizi uygulanmış ve SPSS üç faktör grubunun ele alınacağını belirlemiştir. Faktör gruplarının sınıflandırılmasında 0,40 kriteri kullanılmıştır.

FarmVille oynayanların motivasyonlarına yönelik yapılan faktörlerin analizi toplam varyansın \% 58,855 açıklamaktadır.

Tablo 4: FarmVille Kullanım Motivasyonları ile Faktöler Arasındaki Korelasyon

\begin{tabular}{|l|c|c|c|}
\hline Faktörler & Eğlence ve Kolaylık & Rahatlama ve Kaçış & $\begin{array}{c}\text { Boş Zaman } \\
\text { Değerlendirme } \\
\text { ve Rekabet }\end{array}$ \\
\hline Eğlence ve Kolaylık & 1 & & \\
\hline Rahatlama ve Kaçı̧ &, $776^{\star \star}$ & 1 & 1 \\
\hline $\begin{array}{l}\text { Boş Zamanı Değerlendirme } \\
\text { ve Rekabet }\end{array}$ &, $696^{\star \star}$ &, $738^{\star \star}$ & \\
\hline
\end{tabular}

Yapılan korelasyon analizi sonucunda faktörler arasında ilișki incelendiğinde, eğlence ve kolaylık ile rahatlama ve kaçış faktörleri arasında yüksek derecede pozitif 
bir ilişkinin olduğu $(r=0,776)$ belirlenmiştir. Diğer faktörler arasında da yüksek derecede pozitif ilişkinin olduğu saptanmıştır. Boş zamanı değerlendirme ve rekabet ile rahatlama ve kaçış arasında yüksek oranda pozitif bir ilişki olduğu saptanmıştır. Bu sonuçla da bireylerin birbiri arasında olumlu bir ilişki olduğu görülmüştür. Çıkan bu sonuçlar FarmVille üzerinde geçirilen vakit arttıkça boş zaman değerlendirme ve rekabet ile eğlence ve kolaylık arasındaki ilişkinin arttığının göstergesidir.

Tablo 5: Cinsiyet ile FarmVille Faktörleri Arasındaki Illişki

\begin{tabular}{|l|l|c|c|c|}
\hline Faktörler & Cinsiyet & N & Mean & \multirow{2}{*}{ t değeri } \\
\hline \multirow{2}{*}{ Eğlence ve Kolaylık } & Kadın & 186 & 3,77 & \multirow{2}{*}{, 016} \\
\cline { 2 - 4 } & Erkek & 220 & 3,54 & \multirow{2}{*}{, 326} \\
\hline \multirow{2}{*}{ Rahatlama ve Kaçış } & Kadın & 186 & 3,21 & \\
\cline { 2 - 4 } & Erkek & 220 & 3,12 & \multirow{2}{*}{, 425} \\
\hline \multirow{2}{*}{ Boş Zamanı Değerlendirme ve Rekabet } & Kadın & 186 & 2,87 & \\
\cline { 2 - 4 } & Erkek & 220 & 2,95 & \multirow{2}{*}{} \\
\hline
\end{tabular}

FarmVille oyununu oynayan bireylerin cinsiyetleri ile faktörler arasındaki yapılan $\mathrm{T}$ - testi sonucunda; cinsiyet ile eğlence ve kolaylık faktörleri arasında anlamlı bir farklılığın olduğu $(\mathrm{p}<0,05)$ sonucuna ulașılmıștır. Burada kadın ve erkeklerin FarmVille oyununa bakış açılarının aynı olduğu sonucuna ulaşılmıştır. Diğer faktörler arasında ile anlamalı bir farklılık ( $\mathrm{p}>0,05)$ saptanmamıştır. Kadın ve erkeklerin eğlence ve kolaylık faktörlerine yönelik sorulara verdiği cevaplar düşünüldüğünde, genel olarak kadınların evde geçirdikleri vakitlerin daha çok olması, tarla işlerine olan ilgilerinin erkeklerden daha fazla olması gibi nedenlerin ön planda olduğunu düşündürmektedir.

Tablo 6: Faktörler ile Eğitim Durumu Arasındaki İlişki

\begin{tabular}{|l|l|c|c|c|c|}
\hline Faktörler & & Df & Mean Sq. & F & Sig \\
\hline \multirow{2}{*}{ Eğlence ve Kolaylık } & Gruplar arasında & 4 & 1,741 & \multirow{2}{*}{1,926} & \multirow{2}{*}{, 105} \\
\cline { 2 - 5 } & Gruplar İçerisinde & 401 &, 904 & \\
\hline \multirow{2}{*}{ Rahatlama ve Kaçış } & Gruplar arasında & 4 & 1,900 & \multirow{2}{*}{1,932} &, 104 \\
\cline { 2 - 5 } & Gruplar İçerisinde & 401 &, 984 & \multirow{2}{*}{3,240} & \multirow{2}{*}{, 012} \\
\hline \multirow{2}{*}{$\begin{array}{l}\text { Boş Zamanı Değerlendirme } \\
\text { ve Rekabet }\end{array}$} & Gruplar arasında & 4 & 3,035 &, 937 & \\
\cline { 2 - 5 } & Gruplar İçerisinde & 401 & & \\
\hline
\end{tabular}

Eğitim durumu ile faktörler arasındaki ilişkiye bakıldığında; boş zamanı değerlendirme ve rekabet arasında ( $\mathrm{p}<0,05$ ) anlamlı bir farklılık olduğu tespit edilmiştir. Eğlence ve kolaylık ile rahatlama ve kaçış faktörleri ile eğitim düzeyi arasında ( $\mathrm{p}>0,05$ ) anlamlı bir farklılık bulunamamıştır. Bu da eğitim durumu ile sosyal etkileșimleri arasında herhangi bir şekilde fark gözetmeksizin iletişimde bulunduklarının bir göstergesidir. Bunun nedenlerini bireyler oyunun dinlenmelerine, günlük streslerini atmalarına veya rahatlamalarına yardımcı olması gibi şekillerde açıklamışlardır. 
Tablo 7: Faktörler ile Yapılan Meslek Arasındaki İlișki

\begin{tabular}{|l|l|c|c|c|c|}
\hline Faktörler & & Df & Mean Sq. & F & Sig \\
\hline \multirow{2}{*}{ Eğlence ve Kolaylık } & Gruplar arasında & 6 &, 942 & \multirow{2}{*}{1,033} & \multirow{2}{*}{, 403} \\
\cline { 2 - 5 } & Gruplar İçerisinde & 399 &, 912 & \\
\hline \multirow{2}{*}{ Rahatlama ve Kaçış } & Gruplar arasında & 6 &, 899 & \multirow{2}{*}{, 905} &, 491 \\
\cline { 2 - 5 } & Gruplar İçerisinde & 399 &, 994 & \multirow{2}{*}{2,101} & \multirow{2}{*}{, 052} \\
\hline \multirow{2}{*}{$\begin{array}{l}\text { Boş Zamanı } \\
\text { Değerlendirme ve Rekabet }\end{array}$} & Gruplar arasında & 6 & 1,979 &, 942 & \\
\cline { 2 - 5 } & Gruplar İçerisinde & 399 & & & \\
\hline
\end{tabular}

Tablo 5'te FarmVille oynama faktörleri ile meslek grupları değerlendirildiğinde anlamlı bir farklılığın olmadığı ( $\mathrm{p}>0,05$ ) ortaya çıkmıştır. $\mathrm{Bu}$ da meslek gruplarının bu oyununu oynama da veya bu oyunda etkileşimde bulunma da etkin olmadığını vurgulamaktadır. Yani bireyler oyunu oynarlarken etkileşimde bulundukları kişilerin mesleklerinden ziyade, oyun için faydalı bilgiler, ürünler veya diğer etkileşimlerini dikkate almaktadırlar.

Tablo 8: Cinsiyete ile FarmVille Kullanım Süreleri

\begin{tabular}{|l|l|c|c|c|c|c|}
\hline $\mathbf{X}^{2}=\mathbf{2 , 9 6 9} ; \mathbf{p = ~ , 3 9 6}$ & & 1 saatten az & $\mathbf{1 ~ - ~ 2 ~ S a a t ~}$ & $\mathbf{3 - 4}$ saat & 5 Saat ve üzeri & Toplam \\
\hline \multirow{2}{*}{ Kadın } & $\mathrm{n}$ & 124 & 37 & 14 & 11 & 186 \\
\cline { 2 - 7 } & $\%$ & 66,7 & 19,9 & 7,5 & 5,9 & 100 \\
\hline \multirow{2}{*}{ Erkek } & $\mathrm{n}$ & 148 & 53 & 11 & 8 & 220 \\
\cline { 2 - 7 } & $\%$ & 67,3 & 24,1 & 5,0 & 3,6 & 100 \\
\hline \multirow{2}{*}{ Toplam } & $\mathrm{n}$ & 272 & 90 & 25 & 19 & 406 \\
\cline { 2 - 7 } & $\%$ & 67 & 22,2 & 6,2 & 4,7 & 100 \\
\hline
\end{tabular}

Tablo 6'da yapılan çapraz tablo analizinde kadınların \% 66,7'sinin 1 saatten az süre ile oyunu oynadığı, \% 19,9'unun bir ila iki saat, \% 7,5'inin üç ila dört saat, \% 5,9'unun beş saat ve üzerinde oyunu oynadı̆̆ı saptanmıştır.

Erkeklerin ise \% 67,3'ünün 1 saatten az, \% 24,1'inin bir ila iki saat arasında oynadığı, \% 5'i üç ila dört saat arasında oynadığı, \% 3,6'sının beş saat ve üzeri oyunu oynadığı görülmüştür.

$\mathrm{Bu}$ analiz sonucunda erkeklerin kadınlara oranla FarmVille oyununu daha fazla oynadıkları ve oyuna daha fazla vakit ayırdıkları görülmüştür. Ancak oyuna ayrılan zaman dilimleri arttıkça her iki cinsiyetinde oyuna ilgilerinin azaldığı belirlenmiştir.

Tablo 9: Internet Erișim Yerleri ile Bir Oturumdaki Farmville Kullanım Süreleri

\begin{tabular}{|l|l|c|c|c|c|c|c|}
\hline \multirow{2}{*}{ X2=15,848; $\mathbf{p = ~ , 1 9 8}$} & & Yarım Saatten az & $\mathbf{1}$ saatten az & $\mathbf{1}-\mathbf{2}$ Saat & $\mathbf{3}-\mathbf{4}$ saat & $\begin{array}{c}\mathbf{5} \text { Saat } \\
\text { ve üzeri }\end{array}$ & Toplam \\
\hline \multirow{2}{*}{ Ev } & $\mathrm{n}$ & 175 & 108 & 48 & 8 & 6 & 345 \\
\cline { 2 - 8 } & $\%$ & 50,7 & 31,3 & 13,9 & 2,3 & 1,7 & 100 \\
\hline \multirow{2}{*}{ Okul } & $\mathrm{n}$ & 3 & 2 & 1 & 1 & 1 & 8 \\
\cline { 2 - 8 } & $\%$ & 37,5 & 25 & 12,5 & 12,5 & 12,5 & 100 \\
\hline \multirow{2}{*}{ İşyeri } & $\mathrm{n}$ & 23 & 6 & 4 & 2 & 2 & 37 \\
\cline { 2 - 8 } & $\%$ & 62,2 & 16,2 & 10,8 & 5,4 & 5,4 & 100 \\
\hline \multirow{2}{*}{ İnternet Kafe } & $\mathrm{n}$ & 7 & 7 & 2 & 0 & 0 & 16 \\
\cline { 2 - 8 } & $\%$ & 43,8 & 43,8 & 12,5 & 0 & 0 & 100 \\
\hline \multirow{2}{*}{ Toplam } & $\mathrm{n}$ & 208 & 123 & 55 & 11 & 9 & 406 \\
\cline { 2 - 8 } & $\%$ & 51,2 & 30,3 & 13,5 & 2,7 & 2,2 & 100 \\
\hline
\end{tabular}


Araștırmada kullanılan analiz sonucunda FarmVille büyük çoğunluğunun oyunu oynamak için internet erişimlerini evlerinden sağladıkları belirlenmiştir. Ayrıca kullanıcıların iş yerlerinden de oyunu takip ettiği saptanmıştır. Bireylerin internet erişimini sağladığı yerler ile kullanım süreleri incelendiğinde, erişim sağlanılan yer her neresi olursa olsun, bu oyuna girdikleri ve bu oyunda geçirilen süre arttıkça kişi sayısının azaldığı görülmüştür. Bu da oyunun hem basit oluşu hem de günlük yapılması gereken işlerin belli bir sürede bitirilmesi ve gün içerisinde başka bir uğraşının gerektirmemesi, bu oyunun uzun saatler ayrılmamasının en büyük nedenidir. Ancak araștırmaya katılan bireyler kesin olarak günlük belli aralıklarla oyuna girmekte ve burada vakit geçirmektedirler.

\section{Sonuç}

Oyunların modern yaşam içindeki her yaştan insan tarafından yoğun bir şekilde talep gördüğü bilinmektedir. Öyle ki; bu yoğun talep karşısında yazılımcılar ve yazılım şirketleri hemen hemen her gün yeni bir oyunu piyasaya sürmektedir. Ancak oyunlarla yoğun bir etkileşim içerisinde olan bireylerin elde ettikleri kazanımlar da sorgulanmaktadır. Bu bağlamda yapılan araştırmada FarmVille oyunu oynayanların, bu oyuna ayırdıkları zaman ve bu oyunları oynama nedenleri üzerine yoğunlaşılmıştır. Bu bağlamda yapılan araştırmaya toplam 406 kişi katılmıştır. Bu katılımcılarının cinsiyet dağılımları \%54,2 erkek, \%45,8 kadın olduğu saptanmış, elde edilen bu sonuç oyunun hem erkekler hem de kadınlar tarafından yoğun olarak tercih edildiğini göstermektedir. Çevrimiçi oyunların bireylerin sosyalleşmesindeki rolü ve çok fazla zaman gerektirmesi oyunu oynayan bireylerin çoğunluğunun bekarlardan oluşmasının en temel nedenlerinden birisi olarak durmaktadır. Çünkü oyun kendi içerisinde kullanıcılarına günlük, saatlik ve kimi zaman belli zaman diliminde gerçekleştirilmesi için işler vermekte, yani sorumluklar yüklemektedir. $\mathrm{Bu}$ sorumluklar ise daha fazla boş zamana sahip bireylerin rahatlıkla yapabileceği türden olmaktadır. Yine araștırmaya katılan bireylerin yaklașık \%89'unun kent yaşamı sürdürmesi, buralarda özlemini duyduğu ekip-biçme faaliyetlerini gerçekleştirmediklerini, bu nedenle oyunda bu duygularını tatmin ettiklerini düşündürmektedir. Araștırmadaki faktör analizlerinin sonucunda ise katılımcıların öncelikle oyunu eğlenceli buldukları için tercih ettikleri sonucuna ulașılmıștır. Ayrıca çalışmada kullanılan faktörlerden olan boş zamanı değerlendirme ve rekabet ile rahatlama başlıklarında ilişkinin yoğun olduğu görülmüştür. Dolayısıyla katılımcıların ya boş zamanlarını değerlendirmek ya da kafalarındaki sorunlardan veyahut sorumluklarından kaçmak için bu oyunu oynadıkları saptanmıştır. Bu bağlamda oyun bireylerin rahatladıkları, boş zamanlarını değerlendirdikleri bir alana dönüşmüştür. Kaldı ki elde edilen bu sonuç aynı zamanda bireylerin oyunda geçirdikleri zamanın artmasının onların diğer oyuncularla olan rekabetinin de artmasının temel nedeni olarak değerlendirilmiştir. Diğer bir deyişle FarmVille üzerinde bireyler ne kadar fazla boş zaman geçirirse, diğer oyuncularla o derece oyun bir rekabete girmektedir. Ayrıca bu hem kadınlar hem de erkekler için ayrı ayrı ele alındığında da değişmemektedir. Yani hem kadınlar hem de erkekler oyunda ne kadar vakit geçirirse kendilerini o kadar yoğun rekabet içinde hissetmektedir. Öte yandan oyunların bireylerin sosyalleşmesine olan etkisinin olduğu düşünüldüğünde, bireylerin birbirlerinin eğitim düzeylerine, mesleklerine, yaşadıkları yerleşim yerlerine bakmaksızın etkileşim içine girdikleri görülmüştür. Elde edilen FarmVille'ın bireylerin sosyalleşmesi üzerinde etkisinin olduğu görüşünü kuvvetlendirmektedir. 
Araştırmaya katılan bireylerin, FarmVille oyununu oynadıkları zamanlar incelendiğinde katılımcılardan erkek ve kadınların yaklaşık \%80'ninin günlük iki saatlerini bu oyuna ayırdıkları belirlenmiștir. Dolayısıyla modern insanın en büyük sorunu olarak dile getirilen zamanın belli bir kısmının oyunlarda geçirilmesi, bireylerin rahatlamaya ve sorumluklardan, sorunlardan kaçmaya ne kadar ihtiyaç duyduklarını göstermektedir. Araştırmada elde edilen sonuçlar kısaca değerlendirildiğinde; katılımcıların çoğunlukla sosyalleșme, boş zaman değerlendirme, rahatlama, sorunlardan ve sorumluklardan kaçma gibi sebeplerle oyunu tercih ettikleri görülmüştür. Ancak oyun içerisinde yapılan üretimlerin ve tüketimlerin gerçek yaşamda karşılığının olmayışı, FarmVille'de geçirilen zamanın serbest zaman gibi görünmesine rağmen gerçek bir karşılığının olmayışı nedeniyle boş zaman aktivitesi gibi olarak değerlendirilmesi gerekmektedir. Ayrıca ileride yapılacak çalışmalarda deneysel olarak gerçek dünyada üretim ve tüketim yapanlar ile sanal dünyada üretim ve tüketim yapanların bu faktörler hakkındaki değerlendirmeleri de gözlenebilir. Yapılacak böyle bir çalışma insanların sanal ve gerçek arasındaki düşüncelerinin anlaşılabilmesi içinde önemli olacaktır.

\section{Kaynakça}

Altunışık, R., Coşkun , R., Bayraktaroğlu, S., \& Yıldırım, E. (2007). Sosyal Bilimlerde Araştırma Yöntemleri SPSS Uygulamalı. Sakarya: Sakarya Yayıncılık.

Aristoteles. (1996). S. Bülbül içinde, Zaman Kavramı (s. 9-41). Ankara: İmge Yayınları.

Baudrillard, J. (2006). Kusursuz Cinayet. (N. Sevil, Çev.) İstanbul: Ayrıntı.

Baudrillard, J. (2011). Simülarklar ve Simülasyon (6.Baskı b.). Ankara: Doğu Batı Yayınları.

Binark, M., \& Bayraktutan-Sütçü, G. (2008). Dijital Oyun, Kültür Endüstrisi Olarak. İstanbul: Kalkedon Yayınları.

Dilci, T. (06 Şubat 2015). Çocuklarda yaratıcı zekayı köreltiyor Erişim: 20 Kasım 2018 www.haberturk.com: http://www.haberturk.com/saglik/haber/1039905cocuklarda-yaratici-zekayi-koreltiyor

Durak, N., ve İrğat, M. (2016). Değersizleşme ve Yabancılaşma Bağlamında Tüketim Ahlâkı ve İnsan. İlahiyat Akademi Dergisi, 2(3), 75-88.

Heidegger, M. (2006). Varlık ve Zaman. (Çev. K. H. Ökten,) İstanbul: Agora Kitaplığı.

Huizinga, J. (2006). Homo Ludens, Oyunun Toplumsal Ișslevi Üzerine Bir Deneme. (Çev. M. A. Kılıçbay,) İstanbul: Ayrıntı Yayınları.

Kellner, D. (2013). Medya Gösterisi. İstanbul: Açılım Kitap.

Levinas, E. (2005). Zaman ve Başka. (Çev. Z. Direk,) İstanbul: Metis Yayıncılık.

Marx, K. (2013). Yabancılaşma. (Çev. B. Erdost,) Ankara: Sol Yayınları.

McLean, D., Hurd, A., ve Rogers,, N. (2008). Kraus' Recreation And Leisure In Modern Society. Mississauga, Canada: Jones And Bartlett Publishers.

Mieczkowski, Z. (1990). World Trend in Tourism and Recreation. New York: Peter Lang Publishing.

Tezcan, M. (1993). Boş Zamanlar Sosyolojisi. Ankara: Ankara Üniversitesi Eğitim Bilimleri Fakültesi Yayınları. 
Ulutürk, U. (1 Eylül 2019 ). Sanal Tüketim. Erişim : 25 Mart 2018 https:// www.ugurkanuluturk.com: https://www.ugurkanuluturk.com/singlepost/2017/09/17/SANAL-TÜKETİM

Veal, A. (2003). Definitions of Leisure and Recreation. Australian Journal of Leisure and Receation, 44-52.

Wilensky, H. (1960). Work, Careers and Social Integration. International Social Science, 544 - 560.

www.btk.gov.tr. (11 Nisan 2018). 1 Milyarın Üzerinde Insan Dijital Oyun Oynuyor. Erişim: 25 Nisan 2018 https://www.btk.gov.tr : https://www.btk.gov.tr/ haberler/1-milyarin-uzerinde-insan-dijital-oyun-

www.digitalstrategyconsulting.com. (13 Haziran 2016). Global gaming trends: 10\% of leisure time now spent gaming. Erişim: 18 Mayıs 2018 www. digitalstrategyconsulting.com: http://www.digitalstrategyconsulting.com/ intelligence/2016/06/global_gaming_trends_10_of_leisure_time_now_spent_ gaming.php 
